\title{
PEMBUATAN ADSORBEN DARI KULIT BATANG JAMBU BIJI (Psidium guajava L.) UNTUK MENJERAP LOGAM TEMBAGA (Cu) DAN NIKEL (Ni) PADA LIMBAH CAIR INDUSTRI PELAPISAN LOGAM
}

\author{
PRODUCTION OF ADSORBENT FROM GUAVA BARK (Psidium guajava L.) TO \\ ADSORP COPPER (CU) AND NICKEL (Ni) IN WASTE WATER OF ELECTROPLATING \\ INDUSTRIES
}

\author{
Setiaty Pandia, Muhammad Ferdiyansyah, Febri Maihendra \\ Departemen Teknik Kimia, Fakultas Teknik, Universitas Sumatera Utara, \\ Jl. Almamater Kampus USU, Medan 20155, Indonesia \\ Email : ferdychem@yahoo.com
}

\begin{abstract}
Abstrak
Penelitian ini bertujuan untuk mempelajari pengaruh waktu adsorpsi, suhu adsorpsi, $\mathrm{pH}$, dan rasio bahan baku dengan asam nitrat dalam pembuatan adsorben kulit batang jambu biji dalam menurunkan kadar logam tembaga $(\mathrm{Cu})$ dan nikel $(\mathrm{Ni})$ dalam limbah cair industri pelapisan logam. Bahan - bahan yang digunakan antara lain, limbah cair industri pelapisan logam, kulit batang jambu biji, asam nitrat, dan aquadest. Kulit batang jambu biji dibersihkan dan dihaluskan sampai ukuran 70-80 mesh, kemudian diaktivasi dengan larutan asam nitrat $\left(\mathrm{HNO}_{3}\right) 4 \mathrm{~N}$ dengan variasi rasio kulit batang jambu biji : asam nitrat $1: 1 ; 1: 2$ dan $1: 3 \mathrm{~g} / \mathrm{mL}$ dipanaskan pada suhu 80 ${ }^{\circ} \mathrm{C}$ selama 120 menit. Adsorben kemudian dikeringan di oven pada suhu $110{ }^{\circ} \mathrm{C}$ selama 120 menit. Adsorben dengan hasil analisa bilangan iodin tertinggi digunakan dalam proses adsorpsi logam $\mathrm{Cu}$ (II) dan Ni (II), dimana massa adsorben yang digunakan yaitu sebanyak 2 gram dalam $150 \mathrm{ml}$ limbah cair industri pelapisan logam, kecepatan stirrer $70 \mathrm{rpm}$, variasi waktu adsorpsi 60, 90 dan 120 menit, variasi suhu adsorpsi $35^{\circ} \mathrm{C}, 45^{\circ} \mathrm{C}$ dan $55^{\circ} \mathrm{C}$, dan variasi $\mathrm{pH}$ adsorpsi 2,7 , dan 12. Hasil penelitian memperlihatkan bahwa rasio kulit batang jambu biji : asam nitrat yang terbaik adalah 1:3 g/mL dengan bilangan iodin sebesar 313,020 mg/g. Berdasarkan Baku Mutu Limbah Cair untuk Kegiatan Industri (KepMen LH 51/1995), kandungan tembaga dan nikel dalam limbah cair tidak boleh melampaui $3 \mathrm{mg} / \mathrm{L}$ dan $5 \mathrm{mg} / \mathrm{L}$ untuk industri pelapisan logam. Dari hasil proses adsorpsi yang telah dilakukan, didapat kondisi optimum adsorpsi logam tembaga yaitu pada waktu 60 menit, suhu $35^{\circ} \mathrm{C}$, dan $\mathrm{pH} 7$ serta diperoleh efisiensi penjerapan sebesar $69,1540 \%$, dan logam nikel yaitu pada waktu 60 menit, suhu $35^{\circ} \mathrm{C}$, dan $\mathrm{pH} 7$ serta diperoleh efisiensi penjerapan sebesar $75,1700 \%$, dimana hasil sisa penjerapan ion logam $\mathrm{Cu}^{2+}$ dan $\mathrm{Ni}^{2+}$ yaitu sebesar 2,8077 $\mathrm{mg} / \mathrm{L}$ dan $4,1100 \mathrm{mg} / \mathrm{L}$.
\end{abstract}

Kata Kunci : adsorben, kulit batang jambu biji, tembaga, nikel, bilangan iodin

\begin{abstract}
This research aims to study the effect of adsorption time, adsorption temperature, $p H$, and the ratio of raw materials with nitric acid in the manufacture of bark guava adsorbent in reducing the metals content of copper $(\mathrm{Cu})$ and nickel $(\mathrm{Ni})$ in the metal wastewater industry. Materials used include, among others, industrial metal coating wastes, guava stem bark, nitric acid, and aquadest. Initially the bark of guava stalk was cleansed and mashed 70-80 size, then activated with $4 \mathrm{~N}$ nitric acid $\left(\mathrm{HNO}_{3}\right)$ solution with a variation in the ratio of bark the guava : nitric acid is $1: 1 ; 1: 2$; and 1;3 $\mathrm{g} / \mathrm{mL}$ were heated at $80^{\circ} \mathrm{C}$ for 120 minutes. The adsorbent is then dried in the oven at $110^{\circ} \mathrm{C}$ for 120 minutes. Adsorbent with the highest iodine number analysis results was used in the adsorption process of $\mathrm{Cu}$ (II) Ni(II) metals, wherein the adsorbent mass used was 2 grams in $150 \mathrm{ml}$ of metallic industry liquid waste, 70 rpm stirrer speed, variation of adsorption times are 60, 90, and 120 minutes, variation of adsorption temperatures are $35^{\circ} \mathrm{C}, 45^{\circ} \mathrm{C}$, and $55^{\circ} \mathrm{C}$, and variation of adsorption $\mathrm{pH}$ are 2,7 , and 12 . The result showed that the ratio of bark of guava stem: the best nitric acid was 1: $3 \mathrm{~g} / \mathrm{mL}$ with iodine number of 313,020 $\mathrm{mg} / \mathrm{g}$. Based on Liquid Waste Quality Standard for Industrial Activity (KepMen LH 51/1995), the copper and nickel content in liquid waste should not exceed $3 \mathrm{mg} / \mathrm{L}$ and $3 \mathrm{mg} / \mathrm{L}$ for metal coating industry. From the results of adsorption process that has been done, got the optimum condition of adsorption of copper metal that is at 60 minutes, temperature $35^{\circ} \mathrm{C}$, and $\mathrm{pH} 7$ and obtained the efficiency of adsorption equal to 69,1540\%, and nickel metal that is at 60 minutes, temperature $35^{\circ} \mathrm{C}$, and $\mathrm{pH} 7$ and obtained the efficiency of adsorption equal to $75,1700 \%$, where the result of adsorption the $\mathrm{Cu}^{2+}$ and $\mathrm{Ni}^{2+}$ metal ions are 2,8077 $\mathrm{mg} / \mathrm{L}$ and 4,1100 $\mathrm{mg} / \mathrm{L}$.
\end{abstract}

Keywords : adsorbent, guava stem bark, copper, nickel, iodine number 


\section{Pendahuluan}

Limbah industri pada umumnya merupakan bahan beracun dan berbahaya (B3) yang berasal dari proses produksi sebuah industri. [17]. Limbah yang dikeluarkan industri-industri seperti industri tekstil, penyamakan kulit, dan elektronik biasanya mengandung logam berat yang dihasilkan dari berbagai proses industri [4].

Limbah yang dihasilkan pada sebuah industri berpotensi besar memiliki sifat beracun, misalnya limbah logam tembaga dan nikel [14]. Berdasarkan Baku Mutu Limbah Cair untuk Kegiatan Industri (KepMen LH 51/1995), kandungan tembaga dan nikel dalam limbah cair tidak boleh melampaui $3 \mathrm{mg} / \mathrm{L}$ dan $5 \mathrm{mg} / \mathrm{L}$ untuk industri pelapisan logam.

Salah satu metode yang sering digunakan untuk proses pemisahan ion tembaga dan nikel adalah dengan menggunakan larutan penukar anion cair atau secara kimia. Selain cara tersebut, yaitu reduksi, penukaran ion, adsorpsi menggunakan karbon aktif, elektrolisa, osmosa balik, dan membran filtrasi [9]. Adanya alternatif lain untuk memisahkan tembaga dan nikel dari limbah industri yaitu dengan menggunakan metode biosorpsi. Metode ini merupakan upaya penanggulangan limbah industri pelapisan logam yang cukup bisa diandalkan, terutama harga dan proses mendapatkannya tergolong murah dan memiliki daya penjerapan yang cukup tinggi [11].

Pada daun, kulit batang, dan daging buah jambu biji ternyata mengandung zat tanin. Zat tanin inilah yang mampu dan berperan dalam penjerapan logam berat dari limbah cair. Prinsip inilah yang mendasari penggunaan kulit batang jambu biji sebagai bahan adsorben yang diharapkan mampu menjerap logam berat pada limbah cair khususnya logam $\mathrm{Cu}$ dan $\mathrm{Ni}$ [11].

Teori

Jambu biji kaya akan kandungan kimia, terutama pada daun, batang, dan buah, bahkan pada akarnya. Daun mengandung tanin (11-17\%), minyak atsiri (eugenol), minyak lemak, damar, zat semak, triterpenoid, asam lemak, dan asam apfel. Pada batang khususnya pada kulit terluar mengandung $12-30 \%$ zat tanin, $\mathrm{CaCO}_{3}$, dan damar. Sementara pada buah mengandung asam amino (triptofan, lisin), pektin, kalsium (Ca), fosfor $(\mathrm{P})$, besi $(\mathrm{Fe})$, mangan $(\mathrm{Mn})$, magnesium $(\mathrm{Mg})$, belerang $(\mathrm{S})$, dan vitamin $(\mathrm{A}, \mathrm{B} 1$, dan $\mathrm{C})$ [14].

Senyawa Tanin merupakan kandungan kimia pada jambu biji yang dapat menjerap ion logam berat, merupakan substansi yang tersebar luas dalam tanaman, seperti daun, buah yang belum matang, batang dan kulit kayu.

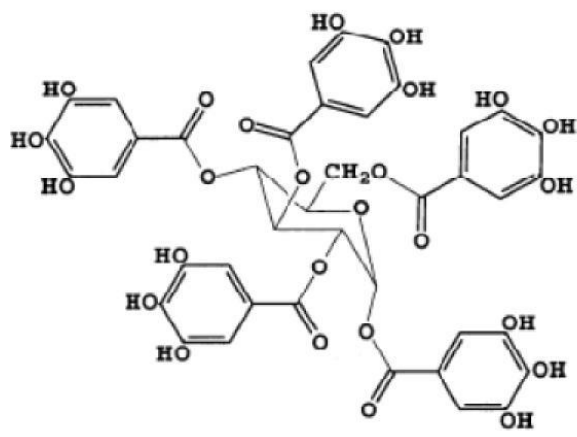

Gambar 1. Struktur Senyawa Tanin [10]

Modifikasi gugus fungsional dapat mengubah sifat-sifat permukaan yang pada akhirnya akan mempengaruhi kemampuan adsorpsi bahan. Untuk meningkatkan kemampuan adsorpsinya, adsorben dapat diaktivasi dengan metode aktivasi kimia (menggunakan asam atau basa) atau aktivasi termal (dengan pemanasan) [12]. Saat ini banyak penelitian-penelitian yang berusaha mengembangkan manfaat tanin. Salah satunya menggunakan tanin sebagai bahan penghambat korosi logam [10].

Logam berat banyak terdapat didalam beberapa limbah industri kimia, misalnya pada industri electroplating, metalurgi, smelting dan lain-lain. Logam berat dalam limbah biasanya berada dalam berbagai kondisi seperti: tidak larut, terlarut, anorganik, tereduksi, teroksidasi, logam bebas, terpresipitasi, terjerap [5].

Tabel 1. Baku Mutu Air Limbah Industri Pelapisan Logam Cu KEP-51/MENLH/ 10/1995

\begin{tabular}{|l|c|c|}
\hline \multirow{2}{*}{ Parameter } & \multicolumn{2}{|c|}{ Pelapisan Tembaga (Cu) } \\
\cline { 2 - 3 } & $\begin{array}{c}\text { Kadar } \\
\text { Maksimum } \\
\text { (mg/L) }\end{array}$ & $\begin{array}{c}\text { Beban } \\
\text { Pencemaran } \\
\text { Maksimum } \\
\left(\mathbf{g}^{2} \mathbf{m}^{2}\right)\end{array}$ \\
\hline TSS & 60 & 60 \\
\hline $\begin{array}{l}\text { Kadmium } \\
(\text { Cd) }\end{array}$ & 0,05 & 0,005 \\
\hline Sianida $(\mathrm{CN})$ & 0,5 & 0,05 \\
\hline Logam Total & 8 & 0,8 \\
\hline Tembaga $(\mathrm{Cu})$ & 3 & 0,3 \\
\hline Nikel (Ni) & - & - \\
\hline pH & \multicolumn{2}{|c|}{$6,0-9,0$} \\
\hline $\begin{array}{l}\text { Debit Limbah } \\
\text { Maksimum }\end{array}$ & \multicolumn{2}{|c|}{ pelapisan logam } \\
\hline
\end{tabular}


Tabel 2. Baku Mutu Air Limbah Industri Pelapisan Logam Ni KEP-51/MENLH/10/1995

\begin{tabular}{|l|c|c|}
\hline \multirow{2}{*}{ Parameter } & \multicolumn{2}{|c|}{ Pelapisan Nikel (Ni) } \\
\cline { 2 - 3 } & $\begin{array}{c}\text { Kadar } \\
\text { Maksimum } \\
\text { (mg/L) }\end{array}$ & $\begin{array}{c}\text { Beban } \\
\text { Pencemaran } \\
\text { Maksimum } \\
\left(\mathbf{g}^{2} \mathbf{m}^{2}\right)\end{array}$ \\
\hline TSS & 60 & 60 \\
\hline $\begin{array}{l}\text { Kadmium } \\
\text { (Cd) }\end{array}$ & 0,05 & 0,005 \\
\hline Sianida $(\mathrm{CN})$ & 0,5 & 0,05 \\
\hline Logam Total & 8 & 0,8 \\
\hline Tembaga $(\mathrm{Cu})$ & - & - \\
\hline Nikel (Ni) & \multicolumn{2}{|c|}{$6,0-9,0$} \\
\hline pH & 100 L per $\mathrm{m}^{2}$ produk \\
\hline $\begin{array}{l}\text { Debit Limbah } \\
\text { Maksimum }\end{array}$ & \multicolumn{2}{|c|}{ pelapisan logam } \\
\hline
\end{tabular}

Berdasarkan hasil analisis laboratorium diketahui bahwa air limbah industri elektroplating mengandung berbagai jenis ion logam berat yang berbahaya bagi lingkungan, khususnya lingkungan perairan sungai. Berbagai jenis ion logam berat yang terkandung di dalam air limbah industri elektroplating seperti ion kromium valensi VI $\left(\mathrm{Cr}^{2+}\right)$, kromium total $(\mathrm{Cr}$ tot $)$, sianida $\left(\mathrm{CN}^{-}\right)$, tembaga $\left(\mathrm{Cu}^{2+}\right)$, seng $\left(\mathrm{Zn}^{2+}\right)$, nikel $\left(\mathrm{Ni}^{2+}\right)$, timbal $\left(\mathrm{Pb}^{2+}\right)$, dan kadmium $\left(\mathrm{Cd}^{2+}\right)$ [5].

\section{Metode Penelitian}

Bahan-bahan yang digunakan dalam penelitian ini yaitu air limbah industri pelapisan logam (bahan utama), kulit batang jambu biji (bahan pembantu), dan bahan-bahan analisanya aquadest, $\mathrm{HNO}_{3} 4 \mathrm{~N}, \mathrm{HCl} 1 \mathrm{M}, \mathrm{NaOH} 1 \mathrm{M}$, iodin $0,1 \mathrm{~N} ; \mathrm{Na}_{2} \mathrm{SO}_{3} 0,1 \mathrm{~N}$; dan indikator amilum $1 \%$.

Peralatan yang digunakan antara lain AAS (Atomic Adsorption Spectroscopy), dan spektrofotometri FT-IR (Fourier Transform Infra Red) sebagai peralatan utama, serta neraca analitik digital, pengaduk magnet, hot plate stirrer, oven, ball mill, $\mathrm{pH}$ universal, kertas saring, corong, ayakan 70 dan 80 mesh, desikator, statif dan klem, alat-alat gelas seperti: gelas kimia, gelas ukur, gelas erlenmeyer, labu takar, pipet volumetrik, pipet tetes, dan buret sebagai peralatan analisa.

Preparasi Kulit Batang Jambu Biji

a. Proses Penyiapan Adsorben

Kulit batang jambu biji dipotong kecil-kecil, kemudian dihaluskan dengan menggunakan ball mill, setelah itu diayak dengan ukuran 70-80 mesh, kemudian dicuci dengan aquadest, dan dikeringkan dibawah sinar matahari selama 5 hari untuk mengurangi kadar air.

b. Pembuatan Adsorben dengan Aktivasi (1:1; $1: 2 ; 1: 3(\mathrm{~g} / \mathrm{mL}))$

Serbuk kulit batang jambu biji yang telah diperoleh kemudian ditimbang sebanyak 1 gram, lalu dimasukkan ke dalam gelas Erlenmeyer, kemudian adsorben diaktifkan dengan larutan $\mathrm{HNO}_{3} 4 \mathrm{~N}$, rasio adsorben : asam nitrat $1: 1 ; 1: 2$; dan $1: 3(\mathrm{~g} / \mathrm{mL})$ dan dipanaskan selama 2 jam pada suhu $80^{\circ} \mathrm{C}$, lalu didinginkan. Setelah dingin, dilanjutkan dengan pencucian sebanyak 2 kali menggunakan air aquadest untuk menghilangkan pengotor terlarut. Kemudian adsorben dimasukkan ke dalam oven selama 2 jam pada suhu $110^{\circ} \mathrm{C}$ untuk mengurangi kadar air, setelah itu adsorben dimasukkan ke dalam desikator untuk melindungi adsorben dari kelembaban.

Tahap Pelaksanaan

1. Pengaruh Waktu Adsorpsi, Suhu Pemanasan, dan $\mathrm{pH}$ pada Adsorben Aktivasi (1:3) Terhadap Efisiensi Penjerapan

Dimasukkan sampel ke dalam 9 gelas Erlenmeyer masing-masing sebanyak $150 \mathrm{ml}$, kemudian ditambahkan 2 gram serbuk kulit batang jambu biji pada masing-masing Erlenmeyer, setelah itu campuran diaduk dengan pengaduk magnet dengan kecepatan 70 rpm selama 60 menit, dikondisikan pada suhu masing-masing $35^{\circ} \mathrm{C}, 45^{\circ} \mathrm{C}$, dan $55^{\circ} \mathrm{C}$, serta $\mathrm{pH}$ masing-masing 2, 7, dan 12. Kemudian disaring dan dianalisa filtrat dengan menggunakan AAS pada $\lambda=324,7 \mathrm{~nm}$. Untuk selanjutnya diulangi prosedur untuk waktu adsorpsi 90, dan 120 menit; suhu 45 dan $55^{\circ} \mathrm{C}$; serta pH 7 dan 12 .

2. Analisis Bahan Adsorben dan Hasil Adsorpsi

Analisis terhadap kulit batang jambu biji sebagai adsorben meliputi analisis bilangan iodin, baik yang diaktivasi (1:3) maupun yang tidak diaktivasi, dan FTIR. Sedangkan analisis terhadap hasil adsorpsi yang dihasilkan meliputi efisiensi penjerapan, dan analisis AAS.

\section{Hasil dan Pembahasan}

1. Analisa Bilangan Iodin

Karbon aktif yang mempunyai daya serap yang tinggi terhadap iodin berarti memiliki luas permukaan yang lebih besar dan struktur mikro dan mesoporous yang lebih besar [7].

semakin meningkatnya rasio aktivator terhadap adsorben yang digunakan, maka daya serap adsorben akan semakin meningkat. Hal ini disebabkan adanya dehidrasi kimia serta kondensasi yang semakin kuat, sehingga menghasilkan struktur pori yang besar [8]. 
2. Pengaruh Waktu Adsorpsi, Suhu, dan $\mathrm{pH}$ Terhadap Efisiensi Penjerapan Ion Logam Tembaga $(\mathrm{Cu})$ dan Nikel (Ni)

Aplikasi adsorpsi ini dicari untuk mengetahui waktu, pH, dan suhu yang dibutuhkan dalam proses adsorpsi ion $\mathrm{Cu}^{2+}$ dan $\mathrm{Ni}^{2+}$ oleh adsorben aktivasi (1:3) hingga tercapai titik maksimum dan mencapai titik kesetimbangan, dimana konsentrasi awal ion logam $\mathrm{Cu}^{2+}$ dan $\mathrm{Ni}^{2+}$ masing-masing pada limbah yaitu 9,2098 mg/L dan $16,55 \mathrm{mg} / \mathrm{L}$.

Gambar 2 merupakan grafik pengaruh waktu adsorpsi dan suhu adsorpsi terhadap efisiensi penjerapan pada $\mathrm{pH} 2$ dengan adsorben aktivasi (1:3).

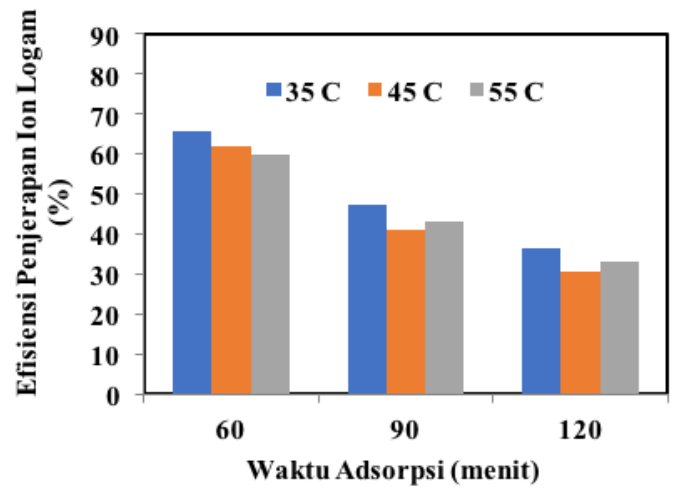

(a)

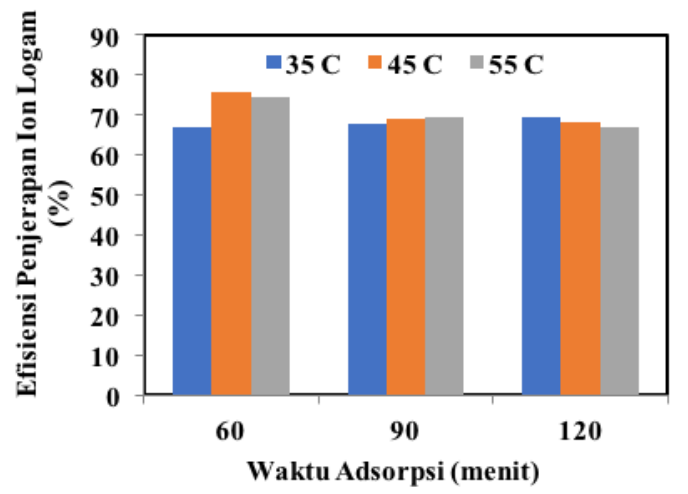

(b)

Gambar 2. Pengaruh Waktu Adsorpsi dan Suhu Adsorpsi terhadap Efisiensi Penjerapan pada pH 2 (a. $\mathrm{Cu}$, b. Ni)

Gambar 2 menunjukkan pengaruh waktu adsorpsi dan suhu adsorpsi terhadap efisiensi penjerapan pada $\mathrm{pH} 2$ dengan adsorben aktivasi (1:3), pada gambar 2(a) dapat dilihat waktu adsorpsi 60 menit terjadi penurunan efisiensi penjerapan seiring meningkatnya suhu, dan pada waktu adsorpsi 90 dan 120 menit efisiensi penjerapan ion logam Tembaga $(\mathrm{Cu})$ oleh adsorben terjadi proses fluktuatif seiring meningkatnya suhu adsorpsi.
Pada gambar 2(b) dapat dilihat waktu adsorpsi 60 menit efisiensi penjerapan ion logam Nikel (Ni) oleh adsorben terjadi proses fluktuatif seiring meningkatnya suhu adsorpsi, pada waktu adsorpsi 90 menit terjadi peningkatan efisiensi penjerapan seiring meningkatnya suhu, dan pada waktu adsorpsi 120 menit terjadi penurunan efisiensi penjerapan seiring meningkatnya suhu.

Berdasarkan waktu adsorpsi dapat dilihat terjadi penurunan efisiensi penjerapan ion logam Tembaga $(\mathrm{Cu})$ pada waktu 90 dan 120 menit, disebabkan karena adsorben sudah mengalami titik kejenuhan, sehingga terjadi proses desorpsi ketika proses pengadukan sedang berlangsung.

Serta pada ion logam Nikel (Ni) pada waktu 90 menit, suhu $35^{\circ} \mathrm{C}$, terjadi peningkatan efisiensi penjerapan pada waktu 120 menit, suhu $35^{\circ} \mathrm{C}$. Hal ini disebabkan karena proses pengadukan yang kurang konstan.

Gambar berikut merupakan grafik pengaruh waktu adsorpsi dan suhu adsorpsi terhadap efisiensi penjerapan pada $\mathrm{pH} 7$ dengan adsorben aktivasi (1:3).

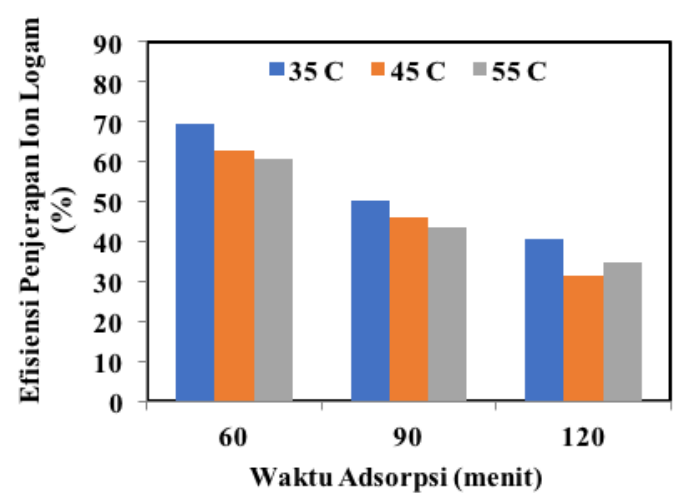

(a)

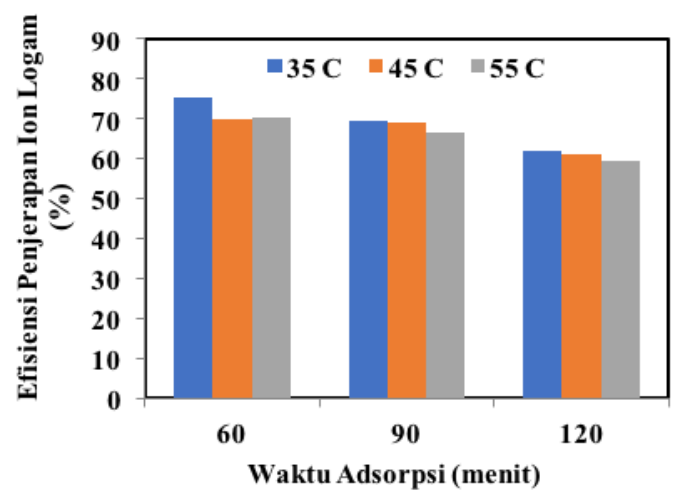

(b)

Gambar 3. Pengaruh Waktu Adsorpsi dan Suhu Adsorpsi terhadap Efisiensi Penjerapan pada pH 7 (a. $\mathrm{Cu}$, b. Ni) 
Gambar 3 menunjukkan pengaruh waktu adsorpsi dan suhu adsorpsi terhadap efisiensi penjerapan pada $\mathrm{pH} 7$ dengan adsorben aktivasi (1:3), pada gambar 3(a) dapat dilihat waktu adsorpsi 60 dan 90 menit terjadi penurunan efisiensi penjerapan ion logam Tembaga $(\mathrm{Cu})$ seiring dengan meningkatnya suhu, dan pada waktu adsorpsi 120 menit efisiensi penjerapan ion logam Tembaga $(\mathrm{Cu})$ oleh adsorben cenderung mengalami fluktuatif seiring meningkatnya suhu adsorpsi.

Pada gambar 3(b) dapat dilihat waktu adsorpsi 60 menit efisiensi penjerapan ion logam Nikel (Ni) oleh adsorben terjadi proses fluktuatif seiring meningkatnya suhu adsorpsi, dan pada waktu adsorpsi 90 dan 120 menit terjadi penurunan efisiensi penjerapan seiring meningkatnya suhu.

Berdasarkan waktu adsorpsi dapat dilihat terjadi penurunan efisiensi penjerapan ion logam Tembaga $(\mathrm{Cu})$ dan Nikel $(\mathrm{Ni})$ pada waktu 90 dan 120 menit, disebabkan karena adsorben sudah mengalami titik kejenuhan, sehingga terjadi proses desorpsi ketika proses pengadukan sedang berlangsung.

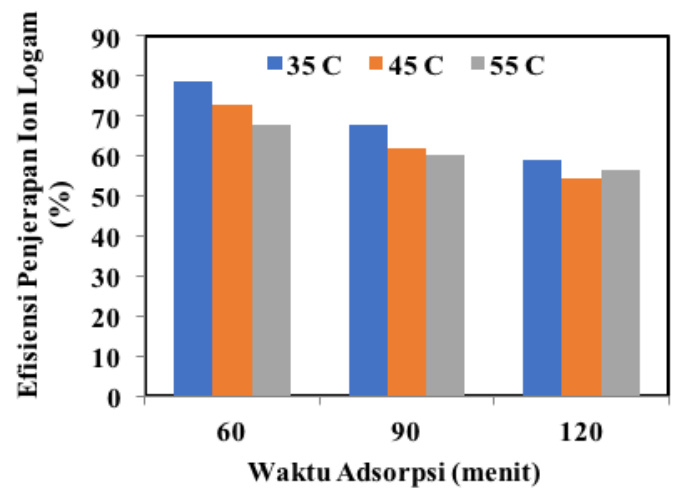

(a)

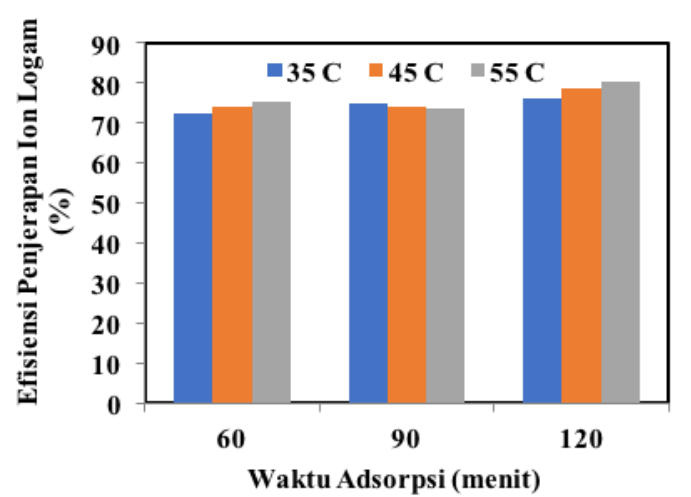

(b)

Gambar 4. Pengaruh Waktu Adsorpsi dan Suhu Adsorpsi terhadap Efisiensi Penjerapan pada pH 12 (a. $\mathrm{Cu}$, b. Ni)
Gambar 4 menunjukkan pengaruh waktu adsorpsi dan suhu adsorpsi terhadap efisiensi penjerapan pada $\mathrm{pH} 12$ dengan adsorben aktivasi (1:3), pada gambar 4(a) dapat dilihat waktu adsorpsi 60 dan 90 menit efisiensi penjerapan ion logam Tembaga $(\mathrm{Cu})$ cenderung menurun seiring meningkatnya suhu adsorpsi, dan pada waktu adsorpsi 120 menit efisiensi penjerapan ion logam Tembaga $(\mathrm{Cu})$ oleh adsorben cenderung mengalami fluktuatif efisiensi penjerapan seiring meningkatnya suhu adsorpsi.

Pada gambar 4(b) dapat dilihat waktu adsorpsi 60 dan 120 menit efisiensi penjerapan ion logam Nikel (Ni) oleh adsorben cenderung meningkat seiring meningkatnya suhu adsorpsi, dan pada waktu adsorpsi 90 menit terjadi penurunan efisiensi penjerapan seiring meningkatnya suhu.

Berdasarkan waktu adsorpsi dapat dilihat terjadi penurunan efisiensi penjerapan ion logam Tembaga $(\mathrm{Cu})$ pada waktu 90 dan 120 menit, disebabkan karena adsorben sudah mengalami titik kejenuhan, sehingga terjadi proses desorpsi ketika proses pengadukan sedang berlangsung. Serta pada ion logam Nikel (Ni) mengalami proses fluktuatif pada waktu 60, 90, dan 120 menit. Hal ini disebabkan karena proses pengadukan yang tidak konstan.

Secara teori, ketika penjerapan adsorben telah mencapai kesetimbangan yakni ketika gugus fungsi pada adsorben telah mengikat ion logam secara maksimal dan setelah kesetimbangan tercapai ikatan antara gugus aktif pada permukaan adsorben dan ion logam melemah sehingga proses desorpsi terjadi karena adanya pengadukan [16].

Pada gambar 2(a), 3(a), dan 4(a) dapat dilihat waktu optimum adsorpsi terjadi pada waktu 60 menit dan efisiensi penjerapan optimum berdasarkan Baku Mutu Limbah Cair untuk Kegiatan Industri (KepMen LH 51/1995) terjadi pada waktu 60 menit, suhu adsorpsi $35^{\circ} \mathrm{C}$ dan $\mathrm{pH} 7$ untuk ion logam Tembaga $(\mathrm{Cu})$, dan pada gambar 2(b), 3(b), dan 4(b) dapat dilihat efisiensi penjerapan optimum berdasarkan Baku Mutu Limbah Cair untuk Kegiatan Industri (KepMen LH 51/1995) terjadi pada waktu 60 menit, suhu adsorpsi $35^{\circ} \mathrm{C}$, dan pH 7 untuk ion logam Nikel (Ni). Hal ini ditetapkan sebagai titik optimum dikarenakan pH awal limbah yaitu 6,8.

Pengaruh suhu terhadap adsorpsi menunjukkan semakin rendahnya kapasitas adsorpsi ketika suhu dinaikkan dikarenakan melemahnya energi ikat antara adsorben dan adsorbat [8]. Adanya kesesuaian teori secara berulang dapat dilihat pada gambar 2(a) yaitu 
pada waktu adsorpsi 60 menit dengan $\mathrm{pH} \mathrm{2,}$ sedangkan pada gambar 3(a) yaitu pada waktu adsorpsi 60 dan 90 menit dengan $\mathrm{pH} 7$, dan pada gambar 4(a) yaitu pada waktu adsorpsi 60 dan 90 menit dengan $\mathrm{pH}$ 12. Pada gambar 2(b) yaitu pada waktu adsorpsi 120 menit dengan $\mathrm{pH} 2$, sedangkan pada gambar 3(b) yaitu pada waktu adsorpsi 90 dan 120 menit dengan $\mathrm{pH}$ 7, dan pada gambar 4(b) yaitu pada waktu adsorpsi 90 menit dengan $\mathrm{pH} 12$.

Dari gambar 2(b), 3(b), dan 4(b) dapat dilihat pengaruh $\mathrm{pH}$ terhadap efisiensi adsorpsi, terlihat bahwa terjadi proses fluktuatif efisiensi penjerapan, hal ini disebabkan kurangnya perhatian pada indikasi pengadukan proses adsorpsi. Sebaliknya gambar 2(a), 3(a), dan 4(a) dapat dilihat pengaruh $\mathrm{pH}$ terhadap efisiensi adsorpsi, terlihat bahwa semakin tinggi $\mathrm{pH}$ adsorpsi semakin tinggi juga efisiensi penjerapan, hal ini disebabkan karena kecilnya presentase ion $\mathrm{Cu}^{2+}$ yang teradsorpsi pada $\mathrm{pH}$ asam yaitu $\mathrm{pH} 2$ dan 7 disebabkan oleh protonasi yang berlebihan pada permukaan adsorben. Selain itu, pada $\mathrm{pH}<7$ spesi ion $\mathrm{Cu}(\mathrm{II})$ yang terbentuk dalam larutan adalah $\mathrm{Cu}^{2+}$ sehingga terjadi persaingan antara proton dan muatan positif dari ion $\mathrm{Cu}^{2+} \mathrm{di}$ permukaan karbon aktif (adsorben) yang menyebabkan kecilnya adsorpsi ion $\mathrm{Cu}^{2+}$ yang terjadi. Adsorpsi ion $\mathrm{Cu}^{2+}$ mengalami peningkatan pada $\mathrm{pH} 7$ hingga 12. Hal ini dikarenakan berkurangnya kompetisi diantara proton $\left(\mathrm{H}^{+}\right)$dan ion logam bermuatan positif $\left(\mathrm{Cu}^{2+}\right)$ di permukaan karbon aktif (adsorben) yang menghasilkan tolakan rendah terhadap ion $\mathrm{Cu}^{2+}$, sehingga ion logam dapat dengan mudah terjerap dalam adsorben [9].

Gambar berikut merupakan hasil spektrum FTIR untuk kulit batang jambu biji tanpa aktivasi.

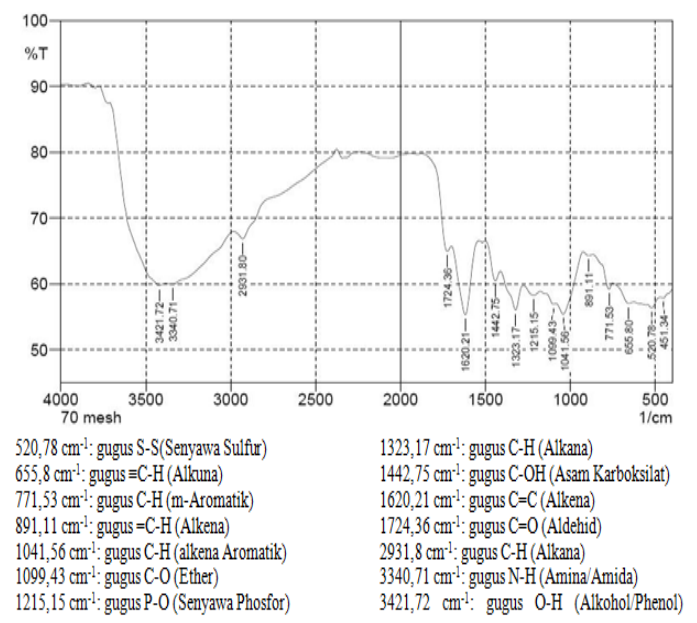

Gambar 5. Hasil Spektrum FTIR untuk Adsorben Kulit Batang Jambu Biji Tanpa Aktivasi

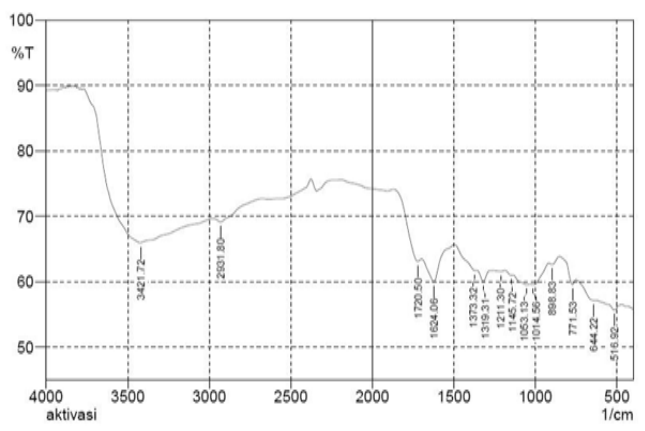

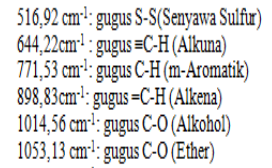

$1145,72 \mathrm{~cm}^{-1}:$ gugus $\mathrm{C}-0$ (Ester)

Gambar 6. Hasil Spektrum FTIR untuk Adsorben Kulit Batang Jambu Biji Dengan Aktivasi

Dari Gambar 5 dan 6 di atas dapat dibandingkan gugus-gugus fungsi yang terdapat pada adsorben sebelum dan sesudah aktivasi. Adsorben sebelum diaktivasi mengandung gugus alkuna, senyawa karbon cincin aromatik, eter, ester, asam karboksilat, gugus $-\mathrm{OH}$ dari alkohol, alkana dan amina. Setelah diaktivasi tidak terdapat lagi amina pada adsorben. Titik didih amina dibawah titik didih air [14].

Pembentukan gugus sulfonil pada adsorben yang terjadi akibat pergeseran pita pada 520,78 $\mathrm{cm}^{-1}$ (pada Gambar 5) menjadi 516,92 $\mathrm{cm}^{-1}$ (Gambar 6) yaitu regangan S-S (senyawa sulfur) yang menunjukkan terjadinya pengikatan oksigen oleh sulfur setelah aktivasi memperlihatkan kemungkinan peningkatan daya adsorpsi oleh adsorben karena gugus sulfonil terlibat pada proses adsorpsi di penjelasan selanjutnya [2].

\section{Kesimpulan}

Hasil penelitian ini memberikan kesimpulan sebagai berikut:

1. Pada adsorben kulit batang jambu biji dengan aktivasi diperoleh hasil bilangan iodin terbesar terjadi pada rasio perbandingan (b:v) 1:3 yaitu dengan ratarata $313,020 \mathrm{mg} / \mathrm{g}$. Sedangkan pada adsorben kulit batang jambu biji tanpa aktivasi diperoleh hasil bilangan iodin rataratanya sebesar 158,625 mg/g.

2. Berdasarkan Baku Mutu Limbah Cair untuk Kegiatan Industri (KepMen LH 51/1995), kandungan tembaga dan nikel dalam limbah cair tidak boleh melampaui $3 \mathrm{mg} / \mathrm{L}$ dan 5 $\mathrm{mg} / \mathrm{L}$ untuk industri pelapisan logam. Dari hasil proses adsorpsi yang telah dilakukan, didapat kondisi optimum adsorpsi ion logam 
$\mathrm{Cu}^{2+}$ yaitu pada waktu 60 menit, suhu $35^{\circ} \mathrm{C}$, dan $\mathrm{pH} 7$ serta diperoleh efisiensi penjerapan sebesar 69,1540\%. Dimana hasil sisa penjerapan ion logam $\mathrm{Cu}^{2+}$ yaitu sebesar 2,8077 $\mathrm{mg} / \mathrm{L}$. Untuk kondisi optimum adsorpsi ion logam $\mathrm{Ni}^{2+}$ yaitu pada waktu 60 menit, suhu $35^{\circ} \mathrm{C}$, dan $\mathrm{pH} 7$ serta diperoleh efisiensi penjerapan sebesar $75,17 \%$. Dimana hasil sisa penjerapan ion logam $\mathrm{Cu}^{2+}$ yaitu sebesar 4,11 mg/L.

3. Dari hasil spektofotometri IR adsorben dapat disimpulkan bahwa aktivasi kimia pada adsorben dapat mereduksi ikatan hidrogen, melepas senyawa aromatik dan mengeliminasi berbagai substrat yang ringan dan volatil serta pada prosesnya. Pada aktivasi menggunakan asam terjadi pertukaran kation dari mineral dengan ion $\mathrm{H}^{+}$ dari asam yang menyebabkan adsorben menjadi bermuatan negatif, sehingga kemampuan penjerapannya meningkat.

\section{Daftar Pustaka}

[1] B. Shrestha, Surface Modification of The Biowaste for Purification of Wastewater Contaminated with Toxic Heavy Metal-Lead and Cadmium, Advances in Chemical Engineering and Science, McGraw Hill, New York, 2013, p. 178-180.

[2] B. Warman, Pemanfaatan Kulit Jengkol Sebagai Adsorben Dalam Penyerapan Logam Cd (II) Pada Limbah Cair Industri Pelapisan Logam, Skripsi, Fakultas Teknik, Jurusan Teknik Kimia, USU, 2016 p. 40-41.

[3] D. Hendra, Pembuatan Arang Aktif Dari Tandan Kosong Kelapa Sawit, Buletin Penelitian Hasil Hutan, Bogor, 1999.

[4] D. Pratiwi, Penentuan Kadar Kromium Dalam Limbah Industri Melalui Pemekatan Dengan Metode Kopresipitasi Menggunakan $\mathrm{Cu}$-Pirolidin Dithiokarbamat, Skripsi, Universitas Negeri Semarang, Kota Semarang, 2013.

[5] E. Suprihatin, Biosorpsi Logam Cu(II) dan Cr(VI) Pada Limbah Elektroplating Dengan Menggunakan Biomassa Phanerochaete Chrysosporium, Jurnal Teknik Kimia, Vol. No. 4, UPN 'Veteran', Jawa Timur, 2009.

[6] K. Sumada, Kajian Instalasi Pengolahan Air Limbah Industri Elektroplating Yang Efisien, Thesis, UPN 'Veteran', Jawa Timur, 2006.

[7] Kwartiningsih, Adsorbsi Logam $\mathrm{Cu}$ Dari Limbah Elektroplating Menggunakan Karbon Aktif Dalam Kolom Fixed Bed, Skripsi, Universitas Negeri Surakarta, Jawa Tengah, 2005.

[8] L. Zhao, Characterization and Adsorptive
Performance of $\mathrm{MgFe}_{2} \mathrm{O}_{4}$ Nanosphere for $\mathrm{SO} 2$ Removal, Journal of Hazardous Materials, 184, 2010, p. 704-709.

[9] L. Zhong, Removal Of Cr(VI) And Cr(III) From Aqueous Solutions And Industrial Wastewaters By Natural Clino-Pymhotite, Environmental Science Technology, China, 2006.

[10] N. Leorita, Uji Daya Serap Ion Logam Berat $\mathrm{Pb}, \mathrm{Cr}$, dan $\mathrm{Cu}$ dari Limbah Sintesis menggunakan Biomaterial Daun Jambu Biji dengan Metode Spektrofotometri Serapan Atom (SSA), Skripsi, Universitas Islam Negeri Sultan Syarif Kasim, Pekanbaru, 2011.

[11] N. Trisna, Pemanfaatan Kulit Batang Jambu Biji (Psidium guajava) Untuk Menyerap Logam Krom Pada Air Limbah Industri Pelapisan Logam, Skripsi, USU, Medan, 2012.

[12] R. Rajeshkannan, M. Rajasimman, dan N. Rajamohan, Decolourization of Malachite Green Using Tamarind Seed: Optimazation, Isotherm, and Kinetic Studies, Chemical Industry \& Chemical Engineering Quarterly, 17(1), 2011, p. 67 -79 .

[13] R. Ticzon, Herbal Medicine Encyclopedia, Romeo R. Ticzon Publishing, ISBN No. 97191-7231-2, Philippines, 1997

[14] S. Hadi, Sifat Fisika dan Kimia Amina, Penerbit Erlangga, Jakarta, 2011, p. 14.

[15] S. Li, dan L. Zhang, Study On Preparation and Characterization of The Adsorbents With Sewage Sludge, Srcosmos, 2010.

[16] S. Solikah dan B. Utami, Perbedaan Penggunaan Adsorben dari Zeolit Alam Teraktivasi dan Zeolit Terimmobilisasi Dithizon Untuk Penyerapan Ion Logam Tembaga $\left(\mathrm{Cu}^{2+}\right)$, Seminar Nasional Kimia dan Pendidikan Kimia VI, Pemantapan Riset Kimia dan Asesmen Dalam Pembelajaran Berbasis Pendekatan Saintifik, Skripsi, Seminar Nasional Kimia dan Pendidikan, 2014, p. 350 - 351.

[17] W. Musu, Otomatisasi Kelayakan Buang Limbah Pertambangan Nikel Menggunakan Partikel Swarm Optimization dan Support Vector Machine, Skripsi, Universitas Hasanuddin, Makassar, 2013. 